\title{
THE RELATIVE ROLES OF LITHOSPHERE AND CONVECTING MANTLE IN KIMBERLITES FROM THE SLAVE PROVINCE, NWT: CONSTRAINTS FROM RE-OS ISOTOPES AND OLIVINE POPULATION STUDIES. D.G. Pearson ${ }^{1}$, G.M. Nowell ${ }^{1}$, D.P. Dowall ${ }^{1}$, B.A. Kjarsgaard ${ }^{2}$, M.G. Kopylova, ${ }^{3}$ and J.A. Armstrong ${ }^{4}$ \\ Arthur Holmes Isotope Geology Laboratory, Durham University, UK, 2 Geological Survey of Canada, Canada, 3, University of British Columbia, Canada, 4 DIAND, Canada
}

\section{INTRODUCTION \& RATIONALE}

The relative contributions of lithospheric mantle and deeper, convecting mantle to the source of kimberlites remains a matter of some debate. The Re-Os isotope system is a powerful tracer in this situation because of the marked difference in ${ }^{187} \mathrm{Os} /{ }^{188} \mathrm{Os}$ between lithospheric mantle and deeper, convecting mantle. Using this approach, Pearson et al. (1995 and in prep) have shown that a powerful argument can be made for the sources of both Group I and Group II (orangeites) kimberlites from southern Africa coming from the convecting mantle, with some magmas being substantially modified by interaction with ancient, depleted lithosphere during their ascent. In this case, the Os isotope ratio of a whole rock kimberlite becomes a sensitive measure of the amount of admixed lithospheric peridotite entrained during passage of the kimberlite through the lithospheric mantle. This isotopic signature can be correlated with whole rock $\mathrm{Ni}$ abundances, and with statistical measurements of olivine abundance and olivine composition studies using the electron probe. In this way, we can try to calculate the amount of peridotite assimilation that is visible and compare this to the amount suggested from Os isotope measurement. Such data can provide an important picture of the amount of potentially diamondbearing lithospheric peridotite that has been assimilated by a given kimberlite.

In this study, we have analysed samples selected from a large suite of well characterised samples from the Lac de Gras field, central Slave province (Dowall et al, this volume) and the Jericho kimberlite in the Contwoyto Lake area (N. Slave Province; Price et al., 2000), for ReOs isotopes. We also discuss new Re-Os isotope data for southern African kimberlites. The emerging Re-Os dataset for Slave kimberlites, combined with the extensive elemental and isotopic database of Dowall et al. (this volume), make the Slave kimberlite province perhaps the best characterised in terms of geochemistry. The data allow us to evaluate the origin of Slave kimberlites within the context of existing petrogenetic models for kimberlites. In addition, it permits valid comparison of the Slave kimberlites to S. African kimberlites in order to further constrain the genesis of the different kimberlite variants.

These Re-Os isotopic studies shed further light on the possible origins of the unusual component in the source of S. African kimberlites characterised by unradiogenic $\mathrm{Hf}$ isotopic compositions at a given $\mathrm{Nd}$ isotope composition (Nowell et al., $1999 \&$ in press).

\section{ANALYTICAL METHODS \& SAMPLES}

Hypabyssal kimberlite, initially selected on a visual basis to be minimally contaminated, was coarsely crushed, followed by removal of any crustal fragments by hand-picking. Samples were subsequently powdered in an agate ball-mill. Those analysed here are a sub-set of the suite of 98 samples analysed for Sr-Nd-Hf isotopic compositions, and major and trace elements by Dowall et al. (this volume). Trace element concentrations in whole rocks were determined by quadrupole ICP-MS at Durham University. Selected samples were then analysed for Re-Os isotopes using the chemical separation techniques outlined by Pearson \& Woodland (2000). Os isotopes were analysed at Durham University using a Thermo-Finnigan Triton mass spectrometer operating in negative ion mode. All signals were measured by peak-hopping on the SEM. Long-term reproducibility of the University of Maryland Os standard for $0.175 \mathrm{ng}$ loads gave a long-term reproducibility for ${ }^{187} \mathrm{Os} /{ }^{188} \mathrm{Os}$ of \pm 1.5 per mil $(\mathrm{n}=80)$. Re was analysed on a Thermo-Finnigan Neptune multicollector ICP-MS using $\mathrm{Tl}$ for mass-bias correction. Olivine population studies were carried out using automated electron microprobe analyses of the cores of olivine macrocrysts followed by statistical analysis. Between 80 and 90 analytical points per thin section were made.

Samples selection for analysis involved screening for crustal contamination on a major element basis using: 1.) the Clement contamination index (CI), and 2.) their $\mathrm{Al}_{2} \mathrm{O}_{3}$ content. $\mathrm{CI}$ on its own may not be particularly successful at identifying kimberlites that have experience crustal contamination, especially where the 
bulk rock contains large proportions of olivine macrocrysts. This is because abundant $\mathrm{MgO}$-rich olivine in a macrocryst-rich kimberlite lowers the CI, counter-balancing effects from crustal contamination, which increases CI. A sample of Jericho aphanitic hypabyssal kimberlite has also been analysed. This is one of the samples proposed by Price et al. (2000) to be close to kimberlitic "primitive melt" compositions.

\section{RESULTS}

\section{OLIVINE POPULATION STUDIES}

Systematic electron-probe analyses of the cores of olivine macrocrysts from Slave hypabyssal kimberlites allows some estimation of the amount of disaggregated peridotitic olivine (xenocrysts) present. The statistical distribution of olivine compositions we obtain for Slave macrocryst-rich kimberlites is very similar to $\mathrm{S}$. African kimberlites. A wide range in olivine mg-number is present ( 87 to 93.6 ). The highest values do not extend quite as high as for macrocrystal S. African kimberlites (Mitchell, 1995) but modes in the distribution from a number of central Slave province kimberlites are very similar to typical Slave and Churchill province lithospheric peridotites (Kopylova et al., 1999; Irvine, 2002; Irvine et al., in press) and show an abundant population of xenocrysts from dissagregated peridotite.

Petrographic observations support this idea, in that many olivine grains contain inclusions of $\mathrm{Cr}$-pyrope or Cr-spinel or $\mathrm{Cr}$-diopside i.e. the olivines are microperidotite xenoliths. In numerous samples, a bimodal olivine distribution was present. In these cases, the mode at low mg -number (87-89) is interpreted to represent the phenocrystal olivine population. No zonation studies have been undertaken so far. Our olivine populations studies, combined with previous contributions (summarised in Mitchell, 1995) indicate that some kimberlites, from the Slave and S. Africa, contain up to $50 \%$ xenocrystal olivine and hence have interacted very significantly with the depleted lithospheric mantle through which they pass on the way to the surface. This creates obvious complications when trying to estimate initial magma compositions.

\section{OS AND RE CONCENTRATIONS}

Positive correlations occur between $\mathrm{Ni}, \mathrm{Cr}$ and $\mathrm{Os}$ concentrations in the whole rock kimberlite suite from southern Africa (Pearson et al., 1995). These correlations, together with the very high Os concentrations observed in some samples ( 2 to $>3 \mathrm{ppb}$ ) are strong evidence of the assimilation of depleted, high $\mathrm{Ni}$, Os-rich lithospheric peridotite (see also isotopic evidence). The correlation between $\mathrm{Ni}$ and Os probably has 2 super-imposed trends; one resulting from peridotite (olivine) assimilation and mixing, and another that results from low-pressure liquidus olivine fractionation, magma mixing and possible flowdifferentiation and segregation. Some scatter probably also results because not all olivine mixed into kimberlite has high Os content. High-Os chromite assimilation will also affect the trend. The general correlation of Os with $\mathrm{Ni}$ is also evident in the Slave kimberlites and, together with the olivine population studies, shows that the dissagregation and entrainment of Os-rich, depleted lithospheric peridotite is a very common phenomena occurring in Slave kimberlites and kimberlites in general.

Because of the complications arising from assimilation of lithospheric olivine, we largely focussed our sample selection for Re-Os isotope analysis on kimberlites that have moderate to lower Ni concentrations (below 1600 ppm where possible), with the aim of better accessing the isotopic composition of the pre-assimilation kimberlite magma. We recognise that this imposes an obvious bias on our sample set. As such, the data are not representative of the whole spectrum of hypabyssal Slave kimberlites, but of those that we believe to be least contaminated by crust and least affected by lithospheric assimilation. We also acknowledge that applying these sample-screening criteria does not fully ensure that the samples are free of effects related to crust or peridotite assimilation.

Os concentrations in Slave kimberlites measured so far range from $0.25 \mathrm{ppb}$ (Porpoise) to $2.4 \mathrm{ppb}$ (Misery-East), with a median value and mode of approximately $1.5 \mathrm{ppb}$, within error of the median value and mode for Kaapvaal kimberlites. These values are typical, or at the upper end of Os concentrations reported for picritic magmas world-wide (e.g., Shirey \& Walker, 1998). One aphanitic Jericho sample has an Os content of $1.4 \mathrm{ppb}$. The high Os contents of the Slave and S. African kimberlites (including Group II) are consistent with their origin from olivine-bearing, peridotitic sources.

Re concentrations are variable and some anomalously low $(30 \mathrm{ppt})$. The low values probably result from Reloss during magma outgassing, a phenomenom identified from the study of melt-inclusions in basaltic magmas (Sun et al., in press). Re concentrations are systematically higher in southern African Group II kimberlites (200-600 ppt; Pearson et al., 1995) than Group I kimberlites (20 to $200 \mathrm{ppt}$ ). The lower volatile contents 
of Group II kimberlites compared to Group I, might result in less Re-loss by outgassing.

\section{RE-OS ISOTOPES}

${ }^{187} \mathrm{Os} /{ }^{188} \mathrm{Os}$ for a range of Lac de Gras kimberlites varies from 0.11599 to 0.141 . These values translate into gamma Os values from -8.9 to +10.6 . The lower Ni, lower Os kimberlites, including the aphanitic Jericho sample, have Os isotopic compositions (gamma Os $=0$ to +10$)$ that are entirely within the OIB field and are consistent with the parental magmas to these rocks originating within the convecting mantle. As Os contents drop below $0.5 \mathrm{ppb}$ samples become more susceptible to contamination by radiogenic Archean crust and caution must be exercised in the interpretation of isotopic signatures from these samples.

Substantial within pipe/cluster isotopic variation exists. A samples from the Misery kimberlite has a gamma Os value of +0.5 whereas from the adjacent Misery-East kimberlite has the lowest gamma Os value for any Slave kimberlite analysed thus far, of -8.9. The large range of Os isotopic compositions shown by the Slave kimberlites is very similar to that of southern African kimberlites (Pearson et al., 1995). This range most likely represents variable assimilation of lithospheric peridotite during ascent and is accompanied by a good positive correlation between Os isotopic composition and $1 / \mathrm{Os}$ concentration, indicative of 2-component mixing. ${ }^{187} \mathrm{Os} /{ }^{188} \mathrm{Os}$ also correlates inversely with $\mathrm{Ni}$ content. The least radiogenic Os isotope composition overlaps the average Os isotopic composition of typical Slave and Churchill Province lithospheric peridotites (Irvine, 2002; Irvine et al., in press).

Hence, the Os concentration and isotopic results agree with the results of our olivine population studies on macrocrysts, and indicate significant (up to $50 \%$ or more) peridotite incorporation. We cannot tell whether the incorporated peridotite is dunitic, harzburgitic, or lherzolitic in character.

The "transitional" nature of the Hf-Nd-Sr isotope compositions shown by Slave kimb erlites compared to southern African kimberlites (Dowall et al., this volume) is not mirrored by their Os isotope compositions, in the database assembled so far. In addition, we currently see no clear correlation between Os isotope composition and degree of displacement from the mantle $\mathrm{Nd}-\mathrm{Hf}$ isotope array.

Additional data for southern African Group II kimberlites, from Lace and Finsch, have been added to the database of Pearson et al. (1995). The Finsch samples vary in Os isotope composition from ${ }^{187} \mathrm{Os} /{ }^{188} \mathrm{Os}$ of 0.1338 to $0.1188(\mathrm{n}=4)$, with 3 of the 4 sample having gamma Os values between 0 and +10 , i.e., within the OIB range. The correlation between Os isotope composition and Os content in these samples is not so strong as with Group I samples. This might be expected because of the multiple-intrusive nature of the Finsch pipe ( 8 discrete intrusions). Furthermore, the lowest Os concentration has the least radiogenic ${ }^{187} \mathrm{Os} /{ }^{188}$ Os. The lower Os concentrations in this case are more likely to be influenced by mixing with unradiogenic peridotite. Another Group II kimberlite, the Lace locality, has a gamma Os value of $\sim 2$, similar to most of the Finsch samples analysed and close to typical OIB.

\section{DISCUSSION}

\section{CONSTRAINTS ON KIMBERLITE GENESIS}

The variations of Os isotopes, Os concentrations and $\mathrm{Ni}$ contents in kimberlites, together with olivine population studies, make a clear case for the incorporation of abundant peridotite-derived olivine into Slave kimberlites, as seen in southern African kimberlites (Mitchell, 1995). We cannot differentiate what type of peridotite was the source for this olivine on the basis of Os isotopes alone.

The Jericho aphanitic hypabyssal kimberlite, with minimal macrocrystal olivine content, has a gamma Os value of close to zero and an Os content of $1.5 \mathrm{ppb}$. These characteristics are very similar to those measured for the aphanitic Wesselton kimberlite (Pearson et al., 1995), considered by many to be the closest approximation to a primary kimberlite melt available (but still not totally representative of a liquid composition e.g., Mitchell, 1995). The "near-primary" magma composition of the Jericho kimberlites is the subject of some debate. Whether this is the case or not, the Wesselton data on its own can be used to suggest that kimberlite "primary" magma that is uncontaminated by crust or lithospheric peridotite has an Os content of 1 to $1.5 \mathrm{ppb}$ and an OIB-like Os isotope composition.

If the Os concentration of the Wesselton (and Jericho ?) samples is close to that of the original parental melt, this implies that the partition coefficient for Os is greatly reduced in the volatile-rich melting environment, perhaps due to absence of sulfide or metal alloys, such 
that very small degrees of melting are capable of yielding Os concentrations more commonly associated with high levels of melting $(20 \%)$ in peridotite with "normal" volatile content.

It is striking that the most radiogenic Os isotope compositions of the Slave province and southern African Group I kimberlites are very similar to the range shown by OIB's. This is further support that "archetypal" kimberlites originate as melts from the convecting mantle (see summary by Mitchell, 1995). The lack of Os isotope compositions that are more radiogenic than the OIB range, for non-contaminated kimberlites, allows us to rule out a source solely from subducted oceanic crust, as proposed by some experimental studies (e.g., Edgar \& Charbonneau, 1993).

The most radiogenic values of both Group I and Group II kimberlites are very similar (Pearson et al., 1995 and new data presented here). Surprisingly, both are within the OIB field. This observation can be interpreted in various ways within the context of models for kimberlite genesis. Two possibilities are:

The parent magma for both archetypal kimberlites (Slave and southern African Group I variants) and Group II kimberlites originates within the convecting mantle. Group II kimberlites then form by extensive hybridisation within the lithosphere in a different manner and/or with different metasomes than Group I kimberlites (e.g., le Roux, 1986; Haggerty, 1994; Pearson et al., 1995).

2) Group II kimberlites originate from olivinepoor or absent sources such as metasomatic vein assemblages (e.g., Mitchell, 1995), their Os isotopic compositions must then be dominated by assimilated peridotite rather than reflecting an ancient, amphibole-phlogopite-apatite source.

Option 2 would probably dictate than an ancient vein source would produce melts with very radiogenic Os isotopes. In this case, it is surprising that the most radiogenic Os isotopic compositions for Group II kimberlites are totally within the Group I and OIB range. Hence, for the present dataset, we prefer option 1. This option is also supported by Hf-Nd isotope systematics (Nowell et al., in press; Dowall et al., this volume) which show complete overlap in Hf isotope compositions between Slave and S. African Group I and Group II kimberlites. Thus, Re-Os isotopes and Os concentration data suggest that archetypal kimberlites (S. African
Group I and Slave) and Group II kimberlites (orangeites) originate from the melting of olivine-rich peridotitic sources. The parental melt, in both cases, originates in the convecting mantle. Group II kimberlites then experience a different history of interaction and hybridisation with lithospheric components as they pass through the lithospheric mantle. The continuum of $\mathrm{Nd}$ and $\mathrm{Hf}$ isotope compositions indicates that possibly only the age of the assimilated lithospheric components might be different.

\section{CONSTRAINTS ON LAMPROITE GENESIS}

The kimberlite Re-Os data can be compared to that for lamproites and so offer constraints on lamproite petrogenesis. Our expanding Re-Os database (Nowell et al., in prep) shows that most lamproites, including olivine lamproites from Smokey Butte and other Montana localities, have Os isotopic compositions substantially more radiogenic than any kimberlite (including Group II/orangeite) so far measured. Furthermore, most lamproites have substantially lower Os concentrations than Group I and Group II kimberlites. Assuming that the Os content of kimberlite is not totally dominated by lithospheric peridotite assimilation - an assumption justified by the OIB-like isotopic compositions of many - then only a few Os-rich lamproites can be constrained to have similar source mineralogy to Group II kimberlites. Rather, the Re-Os isotope and Os concentration data strongly implicates the dominance of olivine-poor metasomatic veins in the source regions of both leucite- and olivine-lamproites (e.g., Foley, 1993).

The exceptions to this are Prairie Creek and Argyle, which have much less radiogenic Os isotope signatures and Os contents above $1 \mathrm{ppb}$. Whether these exceptions represent extensive hybridization with Osrich lithospheric peridotite that completely dominates the Re-Os characteristics of these particular olivine lamproites (Mitchell \& Bergman, 1991) is being further evaluated.

\section{ACKNOWLEDGEMENTS}

We thank BHP-Billiton, Kennecott, DEBEERS and Tahera Resources for the generous donation of kimberlite samples, without which this and associated kimberlite studies could not have taken place. DGP acknowledges a NERC-JREI instrumentation grant (DUPEEQ) and the University of Durham for funding. 


\section{REFERENCES}

Dowall, D.P., Pearson, D.G., Nowell G.M., Kjarsgaard B.A., Armstrong J.A., Horstwood M.S.A., this volume. Comparative geochemistry of kimberlites from the Lac de Gras field, N.W.T. - an integrated isotopic and elemental study.

Edgar, A.D., Charbonneau, H.E., 1993. Melting experiments on a $\mathrm{SiO} 2$-poor, $\mathrm{CaO}$-rich aphanitic kimberlite from 5-10 $\mathrm{GPa}$ and their bearing on the sources of kimberlite magmas. Am. Min., 78: 132-142.

Foley, S.F. 1993. An experimental study of olivine lamproites: First results from the diamond stability field. Geochim. Cosmochim. Acta. 57: 483-489.

Haggerty, S.E., 1994. Superkimberlites: A geodynamic window to the Earth's core. Earth Planet. Sci.e Lett., $122,57-69$

Irvine, G.J., 2002. Time constraints on the formation of lithospheric mantle beneath cratons: A Re-Os isotope and platinum group element study of peridotite xenoliths from Northern Canada and Lesotho. PhD Thesis, Durham University, Durham, UK.

Irvine, G.J., Pearson, D.G., Carlson, R.W., Kjarsgaard, B.A. \& G. Dreibus in press. Evolution of the lithospheric mantle beneath northern Canada: A Re-Os isotope and PGE study of kimberlite-derived peridotite xenoliths from Somerset Island and a comparison to the Slave and Kaapvaal cratons. Lithos.

Kopylova, M.G., Russell, J.K., Cookenboo, H. 1999. Petrology of peridotite and pyroxenite xenoliths from the Jericho kimberlite: implications for the thermal state of the mantle beneath the Slave craton, northern Canada. Journal of Petrology, 40: 79-104.

le Roux, A.P., 1986. Geochemical correlation between southern African kimberlites and South Atlantic hotspots. Nature, 324, 243-245.

Mitchell, R.H., 1995. Kimberlites, orangeites, and related rocks. Plenum, 410pp.

Mitchell, R.H., Bergman, S.C., 1991. Petrology of lamproites. Plenum, 447 pp.

Nowell, G.M., Pearson, D.G., Kempton, P.D., Noble, S.R. 1999. Origins of kimberlites: a Hf isotope perspective. Proc. $7^{\text {th }}$ IKC, Cape Town, 1998. Red Roof Design, Cape Town, South Africa, pp. 616-624.

Nowell, G.M., Pearson, D.G., (in press). Hf isotope systematics of kimberlites and their megacrysts: new constraints on their source regions. J. Petrology.

Pearson, D.G., Woodland, S.J. 2000. Solvent extraction/anion exchange separation and determination of PGEs (Os, Ir, $\mathrm{Pt}, \mathrm{Pd}, \mathrm{Ru}$ ) and $\mathrm{Re}-\mathrm{Os}$ isotopes in geological samples by isot ope dilution ICP-MS. Chem. Geol.., 165, 87-107.

Pearson, D.G., Rogers, N.W., Irving, A.J., Smith, C.B., Hawkesworth, C.J., 1995. Source regions of kimbelites and lamproites: constraints from Re-Os isotopes. Ext.
Abst. 6th International Kimberlite Conference, Novosibirsk: 430-432.

Price, S.E., Russell, J.K, Kopylova, M.G. (2000). Primitive magma from the Jericho Pipe, N.W.T., Canada; Constraints on primary kimberlite melt chemistry. Journal of Petrology, 41, 789-808.

Shirey, S.B., Walker R.J., 1998. The Re-Os isotope system in cosmochemistry and high-temperature geochemistry. Ann. Rev. Earth and Planet. Sci.., 26, 423-500.

Sun, W. Bennet, V.C., Eggins, S.M., Kamenetsky, V.S. Arculus, R.J. in press. Evidence for enhanced mantle to crust rhenium transfer from undegassed arc magmas. Nature.

Contact: D.G. Pearson, Arthur Holmes Isotope Geology Laboratory, Department of Geological Sciences, Durham University, South Road, Durham, DH1 3LE, UK, E-mail: d.g.pearson@durham.ac.uk 